\title{
Serological Evidence of West Nile Virus Infection in White-Tailed Deer in Central Texas
}

\author{
Pedro M. Palermo, ${ }^{1}$ Jeanette Orbegozo, ${ }^{1}$ John C. Morrill, ${ }^{2}$ and Douglas M. Watts ${ }^{1}$
}

\begin{abstract}
White-tailed deer (WTD) are abundant mammals widely distributed across the United States. As a result, WTD are considered to be excellent sentinels for detecting arboviral activity in certain geographic areas. Evidence of West Nile virus (WNV) antibody in WTD has been reported previously in several states. However, WNV infection in WTD has not been reported from Texas, where the incidence of human West Nile (WN) cases is among the highest in the United States. Therefore, the aim of this study was to determine the prevalence of WNV antibody in WTD in central Texas. Sera samples $(n=644)$ were collected from deer during the fall and winter in western Travis County, Texas from 2014 to 2018 and tested for WNV immunoglobulin G (IgG) antibody by an indirect enzyme-linked immunosorbent assay (ELISA). ELISA antibody-positive samples were further tested for WNV and St. Louis encephalitis virus (SLEV) antibodies by an $80 \%$ plaque-reduction neutralization tests $\left(\mathrm{PRNT}_{80}\right)$. Overall, 9\% $(n=58)$ and $0.31 \%(n=2)$ of the deer samples had serological evidence of WNV and SLEV infections, respectively. WNV seroprevalence differed significantly by age $(p<0.05)$, but there was no significant difference between sex. Interestingly, 3.1\% $(n=20)$ of the samples were positive for Flavivirus IgG antibody by ELISA, but negative for SLEV and WNV antibodies, suggesting that other Flaviviruses may be circulating among WTD in Texas. Finally, these results supported WNV infection among WTD and highlight their potential role as sentinels for the detection of WNV in Texas and warrant further studies to determine the role WTD play in the maintenance and transmission of WNV.
\end{abstract}

Keywords: West Nile, antibodies, deer, Texas

\section{Introduction}

A LTHOUGH WHITE-TAILED DEER (WTD; Odocoileus virginianus) are susceptible to infection by several arboviruses (arthropod-borne viruses), their role in the maintenance and transmission cycle for most of these viruses is poorly understood (Yuill and Seymour 2001). However, as one of the most abundant and widely distributed large ruminant mammal species in North America, testing of sera samples from WTD for arbovirus antibodies has been reported to be a reliable indicator for monitoring arboviral activity (DeNicola et al. 2000, Yuill and Seymour 2001, Farajollahi et al. 2004, Santaella-Tenorio et al. 2005, Mutebi et al. 2011, Nofchissey et al. 2013, Pedersen et al. 2017). Of the Flaviviruses studied, West Nile virus (WNV) antibody has been among the most frequently detected in WTD with seroprevalence ranging from an overall of $6.0 \%$ in deer sampled from 18 U.S. states and the U.S. Virgin Islands, with a high of $18.7 \%$ in Lousiana (Pedersen et al. 2017). In other areas, seroprevalence ranged from $0.9 \%$ in New Jersey (Farajollahi et al. 2004) to $8.5 \%$ in Iowa (Santaella-Tenorio et al. 2005).

West Nile (WN) infection in WTD has not been reported from Texas where the incidence of human WN cases is among the highest in the United States (CDC, 2019). Population density of WTD in Texas has increased dramatically from near extermination in the early 1900s to an estimated population of 5.3 million (Texas Parks and Wildlife Department, 2019). Therefore, because of an opportunity to collect sera samples from WTD, a survey for serological evidence of WNV infection among WTD in suburban and rural communities, with a seasonal circulation of WNV since 2002, was conducted in Travis County, Texas. This serosurvey was also extended to test for St. Louis encephalitis virus (SLEV) antibody. SLEV is the only other Flavivirus, that is, well documented to be enzootic in certain areas of Texas (DSHS 2019).

\footnotetext{
${ }^{1}$ Department of Biological Sciences and Border Biomedical Research Center, University of Texas at El Paso, El Paso, Texas, USA.
}

${ }^{2}$ Orion Research and Management Services, Gatesville, Texas, USA. 


\section{Materials and Methods}

\section{Sample collection}

Blood samples were collected from free ranging, rural, and suburban WTD taken by experienced sharpshooters in accordance with Scientific Permit SPR-0801-168 issued by the Texas Parks and Wildlife Department, Austin, Texas in several different areas in Travis County, Texas from 2014 to 2018 (fall and winter). Initially, deer density in these areas averaged $\leq 4$ acres/deer where, in this region, a deer density of $10-15$ acres/deer is desired. Travis County is located in south-central Texas, between San Antonio and Dallas-Fort Worth. The County is divided by the Colorado River from the northwest to southeast, forming a series of lakes, including Lake Travis, Lake Austin, and Lady Bird Lake. According to the 2010 census, the human population reaches 1,024,266 inhabitants. Travis County altitude ranges from 120 to 400 feet above sea level and its climate is subtropical, with an average low of $4^{\circ} \mathrm{C}$ and a high temperature of $38^{\circ} \mathrm{C}$ during the winter and summer season, respectively. The annual average rainfall is $812 \mathrm{~mm}$. The landscape in western Travis County is dominated by Ashe juniper and mixed hardwood species interspersed with grassland and steepwalled canyons.

The collection sites are all located within Travis County and west of State Highway 183. Four study areas designated as Area A, B, C, and D were identified and 20 collection sites within those areas were established. Areas A, B, and D are separated from one another by 7-10 miles, whereas Area $\mathrm{C}$ is $\sim 20$ miles distant from the other Areas. These Areas are undeveloped land, but some are surrounded by residential and commercial development. Area A is private and local government-owned land closed to the public and bordering the north and south shores of Lake Austin at its western end. Area B consists of tracts of local government-owned land, closed to the public, but surrounded by residential and commercial development and situated between Lake Austin and MoPac Boulevard extending northward to highway 620 . Area $\mathrm{C}$ is rural county-owned property situated at the western edge of Travis County. This Area has public access and is bordered by Lake Travis on the north and the Travis County line on the south and west. This area is $\sim 20$ miles west of Areas A, B, and D. Area D is undeveloped local governmentowned land, closed to public access, bordered by highway 620 on the south, Lake Travis on the west and State Highway 183 on the east and extending northward to the Travis County line.

Data collected on each deer included date, sex, age, and location. Age was determined by a standard dental examination (Cain and Wallace 2003). Blood samples were obtained by postmortem cardiac puncture at a central processing site and transported to the laboratory for processing. Samples were centrifuged at $1200 \times g$ at $4^{\circ} \mathrm{C}$ for $10-15 \mathrm{~min}$ and then the sera were stored in aliquots of one to $2 \mathrm{~mL}$ at $20^{\circ} \mathrm{C}$ until tested for antibodies.

\section{Indirect immunoglobulin G enzyme-linked immunoabsorbent assay}

WTD sera samples were tested for immunoglobulin G (IgG) antibody to WNV by an indirect enzyme-linked immunosorbent assay (ELISA) using a lysate of Vero cells as previously described (Palermo et al. 2019) with slight modifications. In brief, sera samples were diluted at a 1:100 di-
Table 1. Seroprevalence of Flavivirus Antibody IN White-Tailed DeER by Locations in Travis County (2014-2018)

\begin{tabular}{|c|c|c|c|c|}
\hline Location (n) & $\begin{array}{l}W N V \\
\%(\mathrm{n})\end{array}$ & $\begin{array}{c}\text { Suspected } \\
\text { flavivirus } \\
\% \text { (n) }\end{array}$ & $\begin{array}{l}S L E V \\
\%(\mathrm{n})\end{array}$ & $\begin{array}{c}S L E V / W N V \\
\%(\mathrm{n})\end{array}$ \\
\hline Area A (170) & $10.59(18)$ & $1.18(2)$ & 0.59 (1) & \\
\hline Area B (90) & $14.4(13)$ & 4.44 (4) & & \\
\hline Area C (183) & $4.37(8)$ & $3.83(7)$ & & 0.55 (1) \\
\hline Area D (201) & $8.96(18)$ & $3.48(7)$ & & \\
\hline
\end{tabular}

SLEV, St. Louis encephalitis virus; WNV, West Nile virus.

lution in blocking buffer (5\% skim milk, $1 \%$ Tween, in phosphate-buffered saline [PBS] $1 \mathrm{X} \mathrm{pH} \mathrm{7.4)} \mathrm{and} \mathrm{tested} \mathrm{in}$ duplicate against WNV antigen prepared as infected Vero cell lysates, and uninfected lysate cells as a control antigen. Then, 96-well microplates were coated with the cell lysates $(100 \mu \mathrm{L})$ and incubated overnight at $4^{\circ} \mathrm{C}$. The next day, the wells of the microplates were washed with PBS 1X tween $0.1 \%$ and $100 \mu \mathrm{L}$ of each of the diluted sera samples was added to each microplate well. Then, $100 \mu \mathrm{L}$ of a secondary antibody (horseradish peroxidase-conjugated rabbit anti-deer IgG) was added to each well of the microplates, followed by the addition of $100 \mu \mathrm{L}$ of a colorimetric substrate ABTS (2, 2'-Azinobis [3-ethylbenzothiazoline-6-sulfonic acid]diammonium salt). After incubation for $40 \mathrm{~min}$, the optical density (OD) values were recorded at $410 \mathrm{~nm}$.

The cutoff OD value was calculated as the ratio of the OD/sample obtained for the WNV antigen (P) and the Vero uninfected antigen $(\mathrm{N})$. Samples with an OD ratio $(\mathrm{P} / \mathrm{N})>2.0$ were considered positive. A set of six WNV antibodynegative and six WNV antibody-positive deer control sera samples were included in the assay. Positive controls had a WNV $80 \%$ plaque-reduction neutralization tests $\left(\mathrm{PRNT}_{80}\right)$ and a hemagglutination inhibition titers greater than 1:20 (ranging from 1:40 to 1:1280) and were SLEV PRNT 80 antibody negative by neutralization assays. Negative control sera were confirmed to be negative for SLEV and WNV antibodies by neutralization assays.

\section{Plaque reduction neutralization test}

WTD sera samples that were reactive in the indirect IgG ELISA to WNV were also tested by PRNT to WNV (NY-99 strain) and SLEV (TVP 12917 strain). In brief, a 1:10 dilution

Table 2. Distribution of the Optical Densities RATio (P/N) Determined By THE INDIRECT WNV IGG ELISA For the 20 White-TaILed DeEr Sera Samples That Were Negative for WNV/SLEV ANTIBodies

\begin{tabular}{lc}
\hline OD ratio $\left(P / N^{*}\right)$ & No. of deer samples \\
\hline $2-2.5$ & 7 \\
$2.5-3$ & 4 \\
$3-3.5$ & 3 \\
$3.5-4$ & 2 \\
$4-5.2$ & 4
\end{tabular}

$*$ OD ratio was $\geq 2.0$ for antibody positive samples.

ELISA, enzyme-linked immunosorbent assay; IgG, immunoglobulin G; OD, optical density. 
Table 3. Flavivirus Antibody Seroprevalence in White-Tailed Deer by Year in Travis County (2014-2018)

\begin{tabular}{lcccc}
\hline Flavivirus antibodies & $\begin{array}{c}2014(\mathrm{n}=150) \\
\%(\mathrm{n})\end{array}$ & $\begin{array}{c}2015(\mathrm{n}=167) \\
\%(\mathrm{n})\end{array}$ & $\begin{array}{c}2016(\mathrm{n}=21) \\
\%(\mathrm{n})\end{array}$ & $\begin{array}{c}2017(\mathrm{n}=195) \\
\%(\mathrm{n})\end{array}$ \\
\hline WNV & $8(12)$ & $9.58(16)$ & $9.52(2)$ & $11.28(22)$ \\
Flavivirus & $3.33(5)$ & $1.78(3)$ & & $4.1(8)$ \\
SLEV & $0.67(1)$ & & & $4.5(5)$ \\
WNV/SLEV & & & & $0.51(1)$ \\
\hline
\end{tabular}

of the heat-inactivated WTD sera samples were incubated at $4^{\circ} \mathrm{C}$ overnight with 30-60 plaque-forming units (PFU) of either WNV or SLEV suspensions. The next day, mixtures of sera/virus (final sera dilution 1:20) were inoculated on $\mathrm{Ma}$ caca mulatta monkey kidney $\left(\mathrm{LLCMK}_{2}\right)$ and baby hamster kidney (BHK-21) cells for WNV and SLEV neutralization assays, respectively. After 3 to 5 days of incubation, cells were fixed and stained with a naphthol blue-black solution. Virus dose was determined as the mean number of PFU recorded on each of 10 wells cells infected with 30-60 PFU based on testing of an equal volume of a dilution of the virus stock and antibody-negative control deer serum. PFU were counted, and if the sera dilution (1:20) reduced $\geq 80 \%$ of the virus dose, the sample was considered as antibody positive. If samples were positive for SLEV and WNV at 1:20 dilution, twofold serial dilutions were tested (1:20 to 1:640) and endpoint titers of fourfold higher antibody difference between SLEV or WNV were considered to specifically differentiate antibody to either one of the viruses. Otherwise, samples were considered as SLEV/WNV antibody positives. A chi-square test was used to compare antibody seroprevalence with the categorical variables as sex and age. All the statistical analyses were performed using the GraphPad 8.0 (San Diego, CA).

\section{Results}

A total of 644 WTD samples were collected from four areas (A-D) consisting of 20 distinct collection sites in Travis County, Texas, and tested for Flavivirus antibody. The overall antibody prevalence for WNV and SLEV was $9 \%$ and $0.31 \%$, respectively, which varied among areas. Sera from deer collected at Areas A and B had the highest WNV seroprevalence (Table 1). Of all the deer samples, $0.16 \%(n=1)$ had antibody to both WNV and SLEV, and 3.11\% $(n=20)$ were WNV IgG antibody positive (OD ratio $>2.0$ ), but negative for SLEV and WNV neutralizing antibodies (Table 2).

WNV seroprevalence varied from $8 \%$ to $11.28 \%$ from 2014 to 2017 and decreased in 2018 (Table 3). Almost similar numbers of WTD were sampled by sex: male (54.5\%) vs.

Table 4. Flavivirus Antibody Seroprevalence in White-Tailed Deer by SeX in Travis COUNTY (2014-2018)

\begin{tabular}{lccc}
\hline Antibodies & $\begin{array}{c}\text { Male }(351) \\
\%(\mathrm{n})\end{array}$ & $\begin{array}{c}\text { Female }(293) \\
\%(\mathrm{n})\end{array}$ & $\begin{array}{c}\text { Total }(644) \\
\%(\mathrm{n})\end{array}$ \\
\hline WNV & $7.69(27)$ & $10.23(30)$ & $8.8(57)$ \\
Suspected flavivirus & $2.57(9)$ & $3.75(11)$ & $3.11(20)$ \\
SLEV & 0 & $0.34(1)$ & $0.16(1)$ \\
WNV/SLEV & 0 & $0.34(1)$ & $0.16(1)$ \\
\hline
\end{tabular}

female $(45.5 \%)$. No significant differences in the WNV antibody seroprevalence were associated with sex (Table 4).

Age class was categorized into five groups $(0.5,1.5,2.5$, 3.5 , and $\geq 4.5$ years), with a range of 110 to 151 WTD per group. WNV antibody prevalence differed significantly by deer age $(p<0.05)$ (Fig. 1), displaying an increasing trend, being the highest $(18.57 \%)$ in WTD older than 4.5 years.

\section{Discussion and Conclusions}

Our findings documented serological evidence of WNV infection in WTD that were collected between 2014 and 2018 in Travis County, Texas. The overall $9 \%$ and $0.31 \%$ prevalence for WNV and SLEV antibody, respectively for WTD, in Travis County, Texas, represented the first reported information on these two Flaviviruses in the Southwestern regions of the United States. Most of the serosurveys among WTD for WNV antibody have been carried out in the Northeast, Midwest, and Southeast regions of the United States. A survey for WNV and SLEV antibodies among hunter-killed deer in New Jersey in 2001 reported seroprevalence of $0.9 \%$ and $1.6 \%$, respectively (Farajollahi et al. 2004). In Iowa, seroprevalence of WNV among WTD was $7.9 \%$ and $8.5 \%$ in 2002 and 2003, respectively (Santaella-Tenorio et al. 2005). Also, a recent survey of 1,508 WTD from 97 counties in 18 U.S. states (collected between January 2010 and March 2016) revealed serological evidence of infection by three Flaviviruses, including Powassan (4.2\%), St. Louis encephalitis, (3.7\%), and WNV (6.0\%) (Pedersen et al. 2017).

The increase in WNV antibody seroprevalence with age was also reported among WTD in the United States (Pedersen et al. 2017), with peak rates being observed in older deer as in the present study. However, the seroprevalence of WNV antibody did not differ by sex as previously reported for deer in the United States (Pedersen et al. 2017). Furthermore, the WNV antibody seroprevalence was higher in Areas A and B in Travis County than other areas. These areas are surrounded by urban, recreational, and touristic settings and therefore may have supported a higher population density of Culex quinquefasciatus, the primary vector species of WNV in Texas. $C x$. quinquefasciatus breeds in clean and dirty water, ditches, and areas with organic waste, and is widely distributed in Travis County (DSHS 2018). Furthermore, previous studies have indicated that $C x$. quinquefasciatus is an opportunistic feeder on avian and mammal hosts in Texas (Molaei et al. 2007).

In Travis County communities, WNV infection was reported in $13 \mathrm{WN}$ human cases, 31 mosquito pools, and 2 horses from to 2014 to 2018 (DSHS 2018) (Table 5). During that period, WNV activity in Travis County was higher every biennial $(2014,2016,2018)$ than other years 
FIG. 1. Flavivirus antibody seroprevalence in white-tailed deer by age in Travis County (2014-2018).

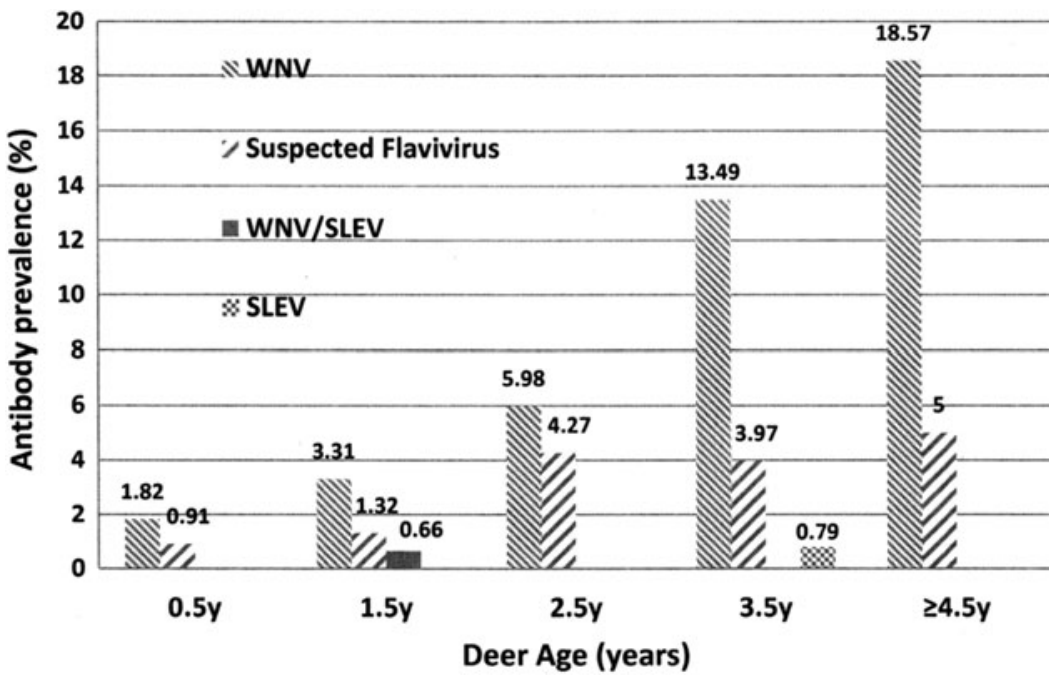

(2015, 2017), when WNV activity was minimal or zero. Burnet and Williamson are neighboring counties to the north and west of Travis County. WNV activity in Williamson County (WNV infections in 4 human WN cases, 30 mosquito pools and 1 horse) had a similar trend as Travis County from 2014 to 2018, while only 1 WNV-infected horse was reported in Burnet County at the same period.

The increased WNV activity in Travis County might have contributed to the WNV antibody seroprevalence observed among WTD (Table 3). Interestingly, WNV activity was not reported among humans in Travis County in 2019 (DSHS 2019); however, deer sera have not yet been tested from Travis County in 2019 to determine if the absence of human cases was reflected by a decrease of antibody in WTD.

As observed during our study, antibody suggestive of an undescribed Flavivirus (non-WNV and non-SLEV) was reported in a deer serosurvey from Iowa using an indirect WNV ELISA (Santaella-Tenorio et al. 2005). In our study, a total of 20 WTD samples were WNV Flavivirus positive (OD >2.0), and 9 of $20(45 \%)$ had an OD ratio $>3.0$ by the ELISA IgG antibody assay (Table 2), suggesting that other Flavivirus(es) had infected WTD in Travis County, Texas. Due to limitations in the volume, samples were not tested for other Flavivirus antibodies. However, evidence of tick-borne Flaviviruses (e.g., Powasan virus [POWV]) infection in WTD was reported

TABle 5. Comparison OF THE WNV ACTIVITY in Travis and Williamson COUNTY and WNV Antibody Seroprevalence in White-Tailed Deer From Travis County (2014-2018)

\begin{tabular}{|c|c|c|c|c|c|c|c|}
\hline \multirow[b]{2}{*}{ Year } & \multicolumn{3}{|c|}{$\begin{array}{c}\text { WNV activity } \\
\text { in Travis } \\
\text { County }\end{array}$} & \multicolumn{3}{|c|}{$\begin{array}{c}\text { WNV activity } \\
\text { in Williamson } \\
\text { County }\end{array}$} & \multirow{2}{*}{$\begin{array}{l}\text { Seroprevalence } \\
\text { of deer WNV } \\
\text { antibody (\%) }\end{array}$} \\
\hline & $H$ & $E$ & $M$ & $H$ & $E$ & $M$ & \\
\hline 2014 & 6 & 1 & 6 & 1 & 0 & 2 & 8 \\
\hline 2015 & 0 & 0 & 0 & 0 & 0 & 2 & 9.58 \\
\hline 2016 & 3 & 1 & 16 & 2 & 1 & 12 & 9.52 \\
\hline 2017 & 0 & 0 & 1 & 1 & 0 & 3 & 11.28 \\
\hline 2018 & 4 & 0 & 8 & 0 & 0 & 11 & 4.50 \\
\hline
\end{tabular}

E, equine; H, human; M, mosquito. in the Northeast and Midwest regions of the United States and Louisiana (5.3\% prevalence to POWV) (Nofchissey et al. 2013, Pedersen et al. 2017).

According to a recent report, evidence of WNV infection has been demonstrated in at least 100 mammalian species (Root and Bosco-Lauth 2019). However, the potential role of most of these mammals, including WTD in the maintenance and transmission cycle of this virus, is unknown. The lack of a virus amplifying role by equine, due to the low and transient viremia levels during WNV infection (Bunning et al. 2002), suggest that WTD may also serve as a dead-end host (Blitvich 2008, Angenvoort et al. 2013). However, WTD are likely to play an important role as a source of blood to sustain the reproduction of the Culex spp. and other vector mosquito species (Molaei et al. 2006, 2008). Finally, this study highlights the importance of WTD for monitoring the distribution of WNV and SLEV and possibly other arboviruses in Texas.

\section{Acknowledgments}

The present study was conducted in accordance with Scientific Permit SPR-0801-168 issued by the Texas Parks and Wildlife Department, Austin, Texas. The authors thank Jim Mobley, David Ashley, Kevin Cagle, Bryan Rugh, Beau Bush, and Susan Bush for their assistance in collecting data and specimens for this study.

\section{Author Disclosure Statement}

No competing financial interests exist.

\section{Funding Information}

This study was supported by the Office Research and Sponsored Projects and by gant 2U54MD007592 from the National Institutes on Minority Health and Health Disparities (NIMHD), a component of the National Institutes of Health (NIH).

\section{References}

Angenvoort J, Brault AC, Bowen RA, Groschup MH. West Nile viral infection of equids. Vet Microbiol 2013; 167:168-180. 
Blitvich BJ. Transmission dynamics and changing epidemiology of West Nile virus. Anim Health Res Rev 2008; 9: 71-86.

Bunning ML, Bowen RA, Cropp CB, Sullivan KG, et al. Experimental infection of horses with West Nile virus. Emerg Infect Dis 2002; 8:380-386.

Cain A, Wallace M. A Guide to Age Determination of Whitetailed Deer. Texas Parks and Wildlife Department. 2003. Available at https://tpwd.texas.gov/publications/pwdpubs/ media/pwd_bk_w7000_0755.pdf. (pp. 1-8).

Centers for Disease Control and Prevention (CDC). West Nile virus disease cases reported to $\mathrm{CDC}$ by states of residence, 1999-2018. Available at https://www.cdc.gov/westnile/ statsmaps/cumMapsData.html.

DeNicola, AJ, Vercauteren KC, Curtis PD, Hygnstrom SE. Managing White-Tailed Deer in Suburban Environments: A Technical Guide. Ithaca, NY: Cornell Cooperative Extension, Cornell University, 2000.

Department of State Health Services (DSHS). 2018 Arbovirus Weekly Activity Reports. Week \#52. 2018. Available at https://www.dshs.texas.gov/idcu/disease/arboviral/westNile/ reports/weekly/.

Department of State Health Services (DSHS). 2019 Arbovirus Weekly Activity Reports. Week \#52. 2019. Available at https://www.dshs.texas.gov/idcu/disease/arboviral/westNile/ reports/weekly/.

Farajollahi A, Gates R, Crans W, Komar N. Serologic evidence of West Nile virus and St. Louis encephalitis virus infections in white-tailed deer (Odocoileus virginianus) from New Jersey, 2001. Vector Borne Zoonotic Dis 2004; 4:379-383.

Molaei G, Andreadis TG, Armstrong PM, Anderson JF, et al. Host feeding patterns of Culex mosquitoes and West Nile virus transmission, northeastern United States. Emerg Infect Dis 2006; 12:468-474.

Molaei G, Andreadis TG, Armstrong PM, Bueno R Jr, et al. Host feeding pattern of Culex quinquefasciatus (Diptera: Culicidae) and its role in transmission of West Nile virus in Harris County, Texas. Am J Trop Med Hyg 2007; 77:73-81. Molaei G, Andreadis TG, Armstrong PM, Diuk-Wasser M. Host-feeding patterns of potential mosquito vectors in
Connecticut, U.S.A.: Molecular analysis of bloodmeals from 23 species of Aedes, Anopheles, Culex, Coquillettidia, Psorophora, and Uranotaenia. J Med Entomol 2008; 45: 1143-1151.

Mutebi JP, Lubelczyk C, Eisen R, Panella N, et al. Using wild white-tailed deer to detect eastern equine encephalitis virus activity in Maine. Vector Borne Zoonotic Dis 2011; 11:1403-1409.

Nofchissey RA, Deardorff ER, Blevins TM, Anishchenko M, et al. Seroprevalence of Powassan virus in New England Deer, 1979-2010. Am J Trop Med Hyg 2013; 88: 1159-1162.

Palermo PM, De la Mora-Covarrubias A, Jimenez-Vega F, Watts DM. Serological evidence of dengue and West Nile virus human infection in Juarez City, Mexico. Vector Borne Zoonotic Dis 2019; 19:134-141.

Pedersen K, Wang E, Weaver S, Wolf P, et al. Serologic evidence of various arboviruses detected in white-tailed deer (Odocoileus virginianus) in the United States. Am J. Trop Med Hyg 2017; 97:319-323.

Root JJ, Bosco-Lauth AM. Review West Nile virus associations in wild mammals: An update. Viruses 2019; 11:459.

Santaella-Tenorio J, Mclean R, Hall J, Gill, J, Bowen, et al. West Nile Virus serosurveillance in Iowa white-tailed deer (1999-2003). Am J Trop Med Hyg 2005; 73:1038-1042.

Texas Parks and Wildlife Department, Austin, Texas. 2019. Available at https://tpwd.texas.gov/landwater/land/habitats/ hillcountry/deer/.

Yuill TM, Seymour C. Arbovirus infections. In: Williams ES, Barker IK, eds. Infectious Diseases of Wild Mammals (3rd $e d n)$. Ames, IA: Iowa State University Press, 2001:98-118.

Address correspondence to: Pedro M. Palermo Department of Biological Science and Border Biomedical Research Center University of Texas at El Paso 500 West University Avenue clo Veterinary Services El Paso, TX 79968

USA

E-mail: ppalermo@utep.edu 